\title{
THE ROYAL SOCIETY OF
}

\section{EDINBURGH}

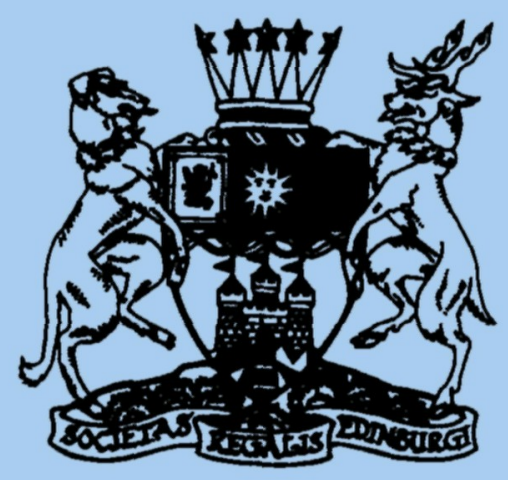

\section{PROCEEDINGS SECTION A}

\section{MAT H E M A T I C S}

PUBLISHED BY THE ROYAL SOCIETY OF EDINBURGH 22 GEORGE STREET, EDINBURGHEH 22 PQ 


\section{EDITORIAL BOARD}

\section{Executive Editors}

E. G. REES (Chairman) University of Edinburgh

J. M. BALL

Heriot-Watt University
K. J. BROWN

Heriot-Watt University

A. M. SINCLAIR

University of Edinburgh
J. C. EILBECK
Heriot-Watt University
A. J. MacinTYRE
W. N. EVERITT
University of Oxford
University of Birmingham
O. Penrose
J. R. HubBuCK
Heriot-Watt University
University of Aberdeen
A. A. RANICKI
University of Edinburgh
F. WILLETT
Curator
University of Glasgow

\section{Consulting Editors}

\section{H. BREZIS}

Université de Paris VI, France

C. M. DAFERMOS

Brown University,

Providence, RI, USA

S. K. DONALDSON

University of Oxford, UK

R. G. Douglas

State University of New York at

Stony Brook, USA

L. E. Fraenkel

University of Bath, UK

M. Giaquinta

Università di Pisa

Italy

J. K. HALE

Georgia Institute of Technology,

USA

\section{K. KIRCHGASSNER}

Universität Stuttgart, Germany

ROBERT V. KOHN

New York University, USA

P. L. LIONS

Université de Paris IX, France

H. Matano

University of Tokyo,

Japan

M. Mimura

Okayama University, Japan
O. A. Oleinik

Moscow State University,

Russia

A. Yu. OlshansKII

Moscow State University,

Russia

D. S. PASSMAN

University of Wisconsin-

Madison, USA

J. M. SANZ-SERNA

Universidad de Valladolid, Spain

W. G. Strang

Massachusetts Institute of

Technology, Cambridge, USA

C. A. Stuart

École Polytechnique Fédérale

de Lausanne, Switzerland

\section{TARTAR}

Carnegie-Mellon University,

Pittsburgh, USA

J. TOLAND

University of Bath, UK

N. S. TRUDINGER

Australian National University,

Canberra, Australia

G. Q. ZHANG

Peking University, Beijing, China

W. A. ZHENG

University of California, Irvine, USA

Publications Manager, Royal Society of Edinburgh: Mrs T. G. Dart

The Royal Society of Edinburgh Proceedings Section A Mathematics is published every two months by the Royal Society of Edinburgh. Subscription price is $£ 219.00$ for six issues (vol. 127). Orders, claims etc. should be addressed to CAB International, Wallingford, Oxon OX10 8DE, U.K. (Tel: (01491) 832111; Fax (01491) 826090) 